\title{
Increased Serum Hepcidin Levels in Children and Adolescents with Attention Deficit Hyperactivity Disorder
}

\author{
Kemal Utku Yazici ${ }^{1}$, Ipek Percinel Yazici ${ }^{1}$, Bilal Ustundag ${ }^{2}$ \\ ${ }^{1}$ Department of Child and Adolescent Psychiatry, ${ }^{2}$ Department of Biochemistry, Firat University Medical Faculty, Elazig, Turkey
}

\begin{abstract}
Objective: In this study, we aimed to evaluate the serum hepcidin levels in attention deficit hyperactivity disorder (ADHD) patients that were newly diagnosed with no history of psychotropic drugs.

Methods: A total of 70 ADHD patients and 69 healthy controls were enrolled in our study. During the diagnosis, the Schedule for Affective Disorders and Schizophrenia for School-Age Children-Present and Lifetime version were applied. The sociodemographic data form, Turgay DSM-IV-Based Child and Adolescent Behavior Disorders Screening and Rating Scale, and Conners' Rating Scales-Revised: Long Form were used for the clinical evaluation. Serum hepcidin levels were measured and compared between the groups.

Results: No significant difference between the groups in terms of age $(p=0.533)$ and gender $(p=0.397)$ was determined. In addition, the groups did not differ significantly for the other sociodemographic variables recorded. Serum hepcidin levels were found to be significantly higher in the patients with ADHD than healthy controls $(p=0.019)$.

Conclusion: To the best of our knowledge, this study is the first to evaluate the total serum hepcidin levels in ADHD patients. Our study findings may suggest that high levels of hepcidin may cause iron dysregulation in ADHD patients. However, further studies are required to establish a definite conclusion.
\end{abstract}

KEY WORDS: Adolescent; Attention deficit disorder with hyperactivity; Child; Hepcidins; Iron.

\section{INTRODUCTION}

Attention deficit hyperactivity disorder (ADHD) is the most common neuropsychiatric disorder in childhood. The mean prevalence of this disorder was found to be $5.9 \%$ in a recent meta-analysis study. ${ }^{1)}$ Although ADHD has been described as a clinical condition for many years, ${ }^{2)}$ its etiology is still unclear. ${ }^{3)}$ However it is commonly considered to develop as a result of interactions between genetic and environmental factors. ${ }^{4)}$

Iron is a key element in the body and has an important role in many biological events, including basic brain function. ${ }^{5)}$ Iron deficiency has been shown to affect catecholamine metabolism, particularly in dopamine, and

Received: November 6, 2017 / Revised: January 2, 2018 Accepted: January 3, 2018

Address for correspondence: Ipek Percinel Yazici, MD Department of Child and Adolescent Psychiatry, Firat University Medical Faculty, 23119 Elazig, Turkey

Tel: +90-507-7864627, Fax: +90-424-2379138

E-mail: ipek.pr@hotmail.com

ORCID: https://orcid.org/0000-0002-6807-655X may lead to ADHD symptoms accordingly. ${ }^{6)}$ Iron deficiency is also thought to be associated with ADHD due to the following factors: 1) iron is the major cofactor of tyrosine hydroxylase enzyme, which is a rate-limiting step in dopamine synthesis ${ }^{7)}$; 2) iron deficiency has been shown to affect dopamine receptor density and transport in the brain in animal researches ${ }^{8,9)}$; and 3) iron deficiency causes functional impairment in dopamine-rich basal ganglia, ${ }^{10)}$ which is thought to have an important role in the formation of ADHD. ${ }^{11)}$ Iron deficiency has been shown to affect cognitive, motor, social and emotional functions in children ${ }^{12)}$ and is therefore, thought to have a role in ADHD pathophysiology. ${ }^{13)}$

The number of studies conducted to gain a better understanding of the relationship between iron deficiency and ADHD pathophysiology has increased in recent years. ${ }^{13,14)}$ Serum iron ferritin levels, which are considered reliable indicators of body iron deposits, are mainly used to determine iron deficiency in these studies. However, the results of current studies on ferritin and ADHD are controversial. In some of these studies, a significant rela-

(c) This is an Open-Access article distributed under the terms of the Creative Commons Attribution Non-Commercial License (http://creativecommons.org/licenses/by-nc/4.0) which permits unrestricted non-commercial use, distribution, and reproduction in any medium, provided the original work is properly cited. 
tionship between ADHD and low serum ferritin levels has been observed, ${ }^{15-23)}$ whereas some reports have found no significant relationship. ${ }^{24-29)}$

Due to these inconsistent results in existing studies, molecules such as hepcidin, which regulates body iron metabolism, have been recommended to determine the relationship between $\mathrm{ADHD}$ and iron deficiency rather than ferritin, which is an indicator of peripheral iron deposits. ${ }^{13)}$

A review of the literature on iron and ADHD have shown that there are two studies that evaluate brain iron levels of $A D H D$ patients through magnetic resonance imaging (MRI). In a study by Cortese et al., ${ }^{21)}$ thalamic iron levels in the ADHD group were found to be significantly lower than the healthy controls. In addition, the authors reported that there was no significant correlation between the brain iron levels and serum ferritin levels. Interestingly, low thalamic iron levels might have a role in the pathophysiology of ADHD. In another study, Adisetiyo et al. ${ }^{30)}$ compared the brain iron indices of medication-naive ADHD patients with brain iron indices of psychostimulant-treated ADHD patients and completely healthy control groups using MRI. In the aforementioned study, the iron indices of striatal and thalamic regions of medication-naive ADHD patients were found to be significantly lower than the other two groups. Interestingly, there was no significant difference in brain iron indices between ADHD patients treated with psychostimulants and healthy control group. Therefore, the authors concluded that the iron homeostasis in the brains of cases with ADHD might be impaired, considering the fact that the brain iron is highly related to the dopaminergic system. ${ }^{31)}$

In 2001, Park et al. ${ }^{32)}$ found a new peptide with liverderived (hep-) and in vitro antibacterial properties (-cidin) in the urine in their studies. Therefore, they named this molecule hepcidin (hepatic bactericidal protein). Currently, hepcidin is accepted as the main hormone in the regulation of iron metabolism. ${ }^{33)}$ Hepcidin is expressed predominantly in the liver ${ }^{32,34)}$; however, studies have also determined that hepcidin is distributed widely in the brain. ${ }^{35)}$ Hepcidin is expressed in the olfactory bulb and various brain regions including cortex, hippocampus, amygdala, thalamus, hypothalamus, mesencephalon, cerebellum and pons. ${ }^{35,36)}$ Considering hepcidin functions in the peripheral tissues, it may be thought that this peptide may also play a central role in the homeostasis of brain iron. In an animal study, astrocytes have been found to reduce iron uptake and release when hepcidin is administered to astrocytes or when astrocytes are infected with an adenovirus expressing hepcidin. It has been suggested that hepcidin may act to reduce the expression of iron transport proteins such as transferrin receptor 1 (TfR1), divalent metal transporter 1 (DMT1), and Ferroportin 1 (FPN1). ${ }^{37)}$

To the best of our knowledge, there is no study investigating the relationship between ADHD and hepcidin in the literature. In the present study, we aimed to evaluate serum hepcidin levels of ADHD patients that were newly diagnosed and had no previous history of psychotropic drug use. We also evaluated iron-related parameters such as ferritin, serum iron, and iron binding capacity in these patients and compared our findings to healthy volunteers.

\section{METHODS}

\section{Study Design}

The study was conducted at the Department of Child and Adolescent Psychiatry in Firat University between December 2014 and October 2016 in accordance with the Declaration of Helsinki (International Committee of Medical Journal Editors, 1989). Prior to participation in this study, the parents of participants provided written informed consent. The Firat University Ethics Committee approved the protocol and informed consent forms for the study (No. 13.01.2015-01-09).

\section{Participants}

A total of 139 subjects, 70 of whom were drug free ADHD children and 69 of whom were healthy controls, were enrolled in the study. The patient group included volunteers: 1) who presented to the Child and Adolescent Psychiatry Outpatient Clinic in Firat University with ADHD symptoms; 2) who were between the ages of 7 to 15 years; and 3) who met the study criteria. The healthy control group included children of the hospital staff or volunteer families with consideration for the age and sex distribution of ADHD group. The socio-demographic characteristics of all cases were recorded on a data form prepared by the researchers. 


\section{Procedures}

\section{Psychiatric evaluation and diagnosis}

In the diagnostic phase, teachers and parents of the children completed the following forms: Turgay DSM-IVBased Child and Adolescent Behavior Disorders Screening and Rating Scale (T-DSM-IV-S) (Parent-Teacher), Conners' Parent Rating Scale-Revised: Long Form (CPRS-R:L), and Conners' Teacher Rating Scale-Revised: Long Form (CTRS-R:L). The CPRS-R:L and CTRS-R:L ADHD were used to evaluate symptom severity. The sociodemographic data forms developed by the researchers were filled out by all participants. Demographic and clinical characteristics, including age, sex, and body mass index (BMI) were recorded.

To diagnose ADHD and other comorbidities in accordance with the Diagnostic and Statistical Manual of Mental Disorders 4th edition (DSM-IV) criteria, an experienced child psychiatrist performed the Schedule for Affective Disorders and Schizophrenia for School Age ChildrenPresent and Lifetime Version (K-SADS-PL). All participants were also evaluated according to the Diagnostic and Statistical Manual of Mental Disorders 5th edition (DSM-5) diagnostic criteria. The Wechsler Intelligence Scale for Children-Revised Short Form (WISC-R) was used to determine the intelligence level of the cases.

Patients were excluded from the study for the following: low intelligence quotient (IQ) below 80 via WISC-R; diagnosis with comorbid psychiatric disorder by K-SADS-PL; a history of psychotropic drug use (including ADHD treatment); acute or chronic systemic diseases; history of head trauma during birth or later; infection during the last month and at the time of assessment; used iron preparations in the last month; and anemia where the hemoglobin level was less than $12 \mathrm{mg} / \mathrm{dl}$ via blood test. The healthy control group included children of hospital staff or volunteer families with consideration for the age and sex distribution of the ADHD group. All of the assessments and exclusion criteria that were given to the patient group (K-SADS-PL, WISC-R, clinical assessment scales) were also applied to the healthy control group.

\section{Instruments used in psychiatric evaluation}

\section{K-SADS-PL}

A semi-structured interview form developed by Kaufman et al. ${ }^{38)}$ was used to determine past and present psychopathologies of children and adolescents according to DSM-IV diagnostic criteria. A validity and reliability study was previously conducted for Turkish samples. ${ }^{39)}$

\section{Socio-demographic Data Form}

This form was developed to determine the socio-demographic characteristics of the cases included in the study. Data included in the form were as follows: for children; age, sex, neuromotor development stages, BMI, literacy learning time, academic achievement, and medical history; for their first/second-degree relatives; education level, occupation, marital status, monthly family income, living place of the parents and psychiatric/medical genealogical information.

\section{T-DSM-IV-S (Parent-Teacher)}

This scale was developed by transforming the DSM-IV criteria into a questionnaire form without changing the meaning. ${ }^{40)}$ It consists of 9 articles questioning inattention, 6 articles questioning hyperactivity, 3 articles questioning impulsivity, 8 articles questioning oppositional defiant disorder, and 15 articles questioning conduct disorder. It was filled out by the mother/father, and teachers of the children considered to have a diagnosis of ADHD before the clinical interview. The options for each article were as follows: $0=$ no, $1=$ little, $2=$ much, $3=$ very much. The validity and reliability study was conducted by Ercan et al. ${ }^{41)}$

\section{CPRS-R:L}

This scale was developed by Conners et al. ${ }^{42)}$ and has been used to evaluate parents' observations about a child's behavior in non-school environments. The Turkish validity and reliability study for the scale was conducted by Kaner et al. ${ }^{43)}$ The scale consists of a total of 80 articles and 14 sub-scales (i.e., oppositional, cognitive problems/ inattention, hyperactivity, anxious/shy, perfectionism, social problems, psychosomatic, ADHD index, Conners' global index-restless/impulsivity, Conners' global indexemotional lability, Conners' global index-total, DSM-IVinattention, DSM-IV-hyperactivity/impulsivity, and DSMIV-total). The questions are answered by both the mother and the father on 4 point Likert scale. 


\section{CTRS-R:L}

This scale was developed to evaluate the classroom behavior of students. ${ }^{44)}$ The Turkish validity and reliability study for this scale was conducted by Kaner et al. ${ }^{45)}$ The scale consists of 59 articles and 13 sub-scales (i.e., oppositional, cognitive problems/inattention, hyperactivity, anxious/shy, perfectionism, social problems, ADHD index, Conners' global index-restless/impulsivity, Conners' global index-emotional lability, Conners' global indextotal, DSM-IV-inattention, DSM-IV-hyperactivity/impulsivity, and DSM-IV-total). The questions are answered by the child's teacher on a 4 point Likert scale.

\section{WISC-R}

This scale measures the intelligence levels of children between the ages of 6 and 16. It was adapted for the Turkish culture by Savaşır and Şahin. ${ }^{46)}$

\section{Biochemical measurements}

After undergoing a psychiatric evaluation, all cases were sent to the Firat University Hospital Biochemistry Laboratory for biochemical measurements. A $6.5 \mathrm{ml}$ of fasting venous blood was taken from all cases between 08:30 AM to 10:30 AM for the evaluation of hemogram, iron, total iron binding capacity (TIBC), and ferritin levels. A $4 \mathrm{ml}$ of blood was collected in a standard biochemistry tube and $2.5 \mathrm{ml}$ of blood was put into a tube containing ethylenediaminetetraacetic acid (EDTA), and the tubes were mixed well. Next, the blood samples were transferred into standard biochemistry tubes, and after $15 \mathrm{mi}$ nutes, serum was obtained by centrifuging for 5 to $10 \mathrm{mi}$ nutes at 4,000 rpm. Iron, iron binding capacity and ferritin levels were measured. Iron and iron binding capacity were determined with Siemens branded commercial kits in Siemens branded fully automatic autoanalyzers (ADVIA 2400, Clinical Chemistry Autoanalyzer; Siemens Co., Munich, Germany). Ferritin levels were measured using a chemiluminescence method with Siemens branded commercial kits in Siemens branded fully automatic hormone analyzers (CENTAUR XP, Hormone Analyzer; Siemens Co.).

Hemogram measurements were performed on the EDTA blood samples in fully automatic blood count devices (HORIBA ABX Hematology Analyzer; HORIBA Ltd., Kyoto, Japan) without delay. Hematocrit, hemoglobin, red blood cell (RBC) count, mean corpuscular volume
(MCV), and red cell distribution width (RDW) were evaluated in hemogram. The results of the blood parameters from all of the cases were evaluated by an experienced biochemistry and clinical biochemistry specialist.

Hepcidin was measured by ELISA (YHB 1535 EIA kit; Shanghai Yahya Biological Technology Co. Ltd., Shanghai, China) according the manufacture's protocol. Intra-assay coefficient of variation was less than $10 \%$ and the inter-assay was less than $12 \%$. The assay range was 10 to 4,000 pg/ml.

\section{Statistical Analysis}

SPSS for Windows statistical package version 22.0 (IBM Co., Armonk, NY, USA) was used for all statistical analyses. All numerical data were expressed as means and standard deviations, while all categorical data were expressed as frequencies and percentages. A chi-square test for categorical variables was used to determine significant differences between groups, while an independent sample $t$ test was used to make comparisons between two groups. A level of $p<0.05$ was determined for statistical significance.

\section{RESULTS}

\section{Socio-demographic Data}

Socio-demographic data of the ADHD group and the healthy control group are presented in Table 1. The mean age of the ADHD group was 10.91 years (standard deviation $[S D], 2.80)$ and was 10.62 years (SD, 2.69) in the control group ( $p=0.533$ ). The ADHD group was $64.3 \%$ male, and the control group was $71 \%$ male $(p=0.397)$. In addition, there were no significant differences between the ADHD and control groups in terms of BMI, total IQ, monthly family income, living place, or parents' education (Table 1).

\section{Biochemical Data}

Biochemical data of the ADHD group and the healthy control group are presented in Table 2. The serum hepcidin level was 1,019.69 (SD, 916.63) pg/ml in the ADHD group and $693.63(\mathrm{SD}, 682.83) \mathrm{pg} / \mathrm{mL}$ in the control group ( $p=0.019$ ). However, there were no significant differences between groups in terms of hematocrit, hemoglobin, MCV, RBC, RDW, serum ferritin, serum iron and TIBC levels (Table 2). 
Table 1. Socio-demographic data of the ADHD and healthy control groups

\begin{tabular}{lccc}
\hline \multicolumn{1}{c}{ Characteristic } & ADHD $(\mathrm{n}=70)$ & $\mathrm{HC}(\mathrm{n}=69)$ & $p$ value \\
\hline Age (yr) & $10.91 \pm 2.80$ & $10.62 \pm 2.69$ & $0.533^{*}$ \\
Gender (\%) & & & $0.397^{\dagger}$ \\
$\quad$ Man & 64.3 & 71 & \\
$\quad$ Woman & 35.7 & 29 & \\
Body mass index $\left(\mathrm{kg} / \mathrm{m}^{2}\right)$ & $20.48 \pm 1.52$ & $20.41 \pm 1.56$ & $0.779^{*}$ \\
Total IQ & $99.22 \pm 5.09$ & $99.68 \pm 5.12$ & $0.603^{*}$ \\
Family income (\%), monthly & & & $0.608^{\dagger}$ \\
$<1,000 \mathrm{TL}$ & 8.6 & 8.7 & \\
1,001-2,000 TL & 32.9 & 39.1 & \\
2,001-3,000 TL & 37.1 & 39.1 & \\
$>3,001 \mathrm{TL}$ & 21.4 & 13.0 & \\
Living place (\%) & & & $0.480^{\dagger}$ \\
City & 60.0 & 69.6 & \\
Town & 30.0 & 21.7 & \\
Village & 10.0 & 8.7 & \\
Mother education (\%) & & & $0.974^{\dagger}$ \\
$\quad$ No education & 2.9 & 1.4 & \\
Elementary school & 22.9 & 26.1 & \\
Secondary school & 34.3 & 33.3 & \\
High school & 28.6 & 27.5 & \\
$\quad$ University & 11.4 & 11.6 & \\
Father education (\%) & & & $0.667^{\dagger}$ \\
$\quad$ No education & 1.4 & 0 & \\
Elementary school & 4.3 & 1.4 & \\
Secondary school & 25.7 & 23.2 & \\
High school & 40.0 & 46.4 & \\
$\quad$ University & 28.6 & 29.0 & \\
\hline Vas & & & \\
\hline
\end{tabular}

Values are presented as mean \pm standard deviation or percent only. $\mathrm{ADHD}$, attention deficit hyperactivity disorder; $\mathrm{HC}$, healthy control; SD, standard deviation; IQ, intelligence quotient; TL, Turkish Lira. *Independent-samples $t$ test, ${ }^{\dagger}$ chi-square test.

\section{DISCUSSION}

In our study, serum hepcidin levels were found to be significantly higher in patients with ADHD than in the control group. However, it is still unclear whether this is a cause or an effect. Iron regulation may be negatively affected in periphery or in the central nervous system of the cases with ADHD due to the high levels of hepcidin. Nowadays, hepcidin is known as an iron-regulatory hormone having an essential role in iron homeostasis in peripheral tissues. ${ }^{33)}$ Hepcidin is expressed predominantly in the liver. ${ }^{32,34)}$ In addition, hepcidin is expressed in the olfactory bulb and various brain regions including cortex, hippocampus, amygdala, thalamus, hypothalamus, mesencephalon, cerebellum and pons. ${ }^{35,36)}$ Considering hepcidin functions in peripheral tissues, this peptide may also play a central role in the homeostasis of brain iron.
Table 2. Biochemical data of the ADHD and healthy control groups

\begin{tabular}{lccc}
\hline \multicolumn{1}{c}{ Variable } & ADHD $(\mathrm{n}=70)$ & $\mathrm{HC}(\mathrm{n}=69)$ & $p$ value* \\
\hline Hematocrit $(\%)$ & $40.67 \pm 2.87$ & $40.90 \pm 2.59$ & 0.632 \\
Hemoglobin $(\mathrm{g} / \mathrm{dl})$ & $13.53 \pm 1.02$ & $13.56 \pm 0.67$ & 0.857 \\
MCV $(\mathrm{fl})$ & $82.92 \pm 4.39$ & $83.34 \pm 3.48$ & 0.539 \\
RBC $(\mathrm{M} / \mu \mathrm{l})$ & $4.94 \pm 0.36$ & $4.95 \pm 0.33$ & 0.833 \\
RDW $(\%)$ & $13.88 \pm 1.05$ & $13.94 \pm 1.21$ & 0.759 \\
Ferritin $(\mathrm{ng} / \mathrm{ml})$ & $27.06 \pm 17.06$ & $27.97 \pm 18.05$ & 0.761 \\
Serum iron $(\mu \mathrm{g} / \mathrm{dl})$ & $72.94 \pm 34.41$ & $74.59 \pm 33.93$ & 0.776 \\
TIBC $(\mu \mathrm{g} / \mathrm{dl})$ & $364.60 \pm 55.86$ & $360.07 \pm 44.32$ & 0.598 \\
Hepcidin $(\mathrm{pg} / \mathrm{ml})$ & $1,019.69 \pm 916.63$ & $693.63 \pm 682.83$ & 0.019 \\
\hline
\end{tabular}

Values are presented as mean \pm standard deviation.

$\mathrm{ADHD}$, attention deficit hyperactivity disorder; $\mathrm{HC}$, healthy control; $M C V$, mean corpuscular volume; RBC, red blood cell count; RDW, reticulocyte distribution width; TIBC, total iron binding capacity. *Independent-samples $t$ test.

According to the literature review, there are several studies suggesting that hepcidin may have a role not only in the regulation of peripheral iron levels, but also in the regulation of iron levels in the central nervous system. $^{36,37,47,48)}$

Preclinical studies have demonstrated that hepcidin can control the amount of iron entering into the brain by regulating the expression of iron-transporting proteins in the endothelial cells of the blood-brain barrier. ${ }^{37,47)}$ The presence of iron transport, uptake, and release proteins in the blood-brain barrier and neuronal and glial cells is well-documented. ${ }^{49-51)}$ FPN1, TfR1, and DMT1 can be among those proteins.

Ferroportine, which is a transmembrane protein, is a receptor for hepcidin, and the only cellular iron dispenser known in vertebrates. ${ }^{52)}$ It secretes iron from cells to plasma. ${ }^{53)}$ However, molecular regulation of iron secretion is carried out by hepcidin through ferroportin modulation. Hepcidin induces internalization of ferroportin through the cell surface. ${ }^{54)}$ Ferroportin has been reported to be present in the brain and neurons. ${ }^{55)}$ Ferroportin is localized in most cell types, including neuronal pericaria, axons, dendrites, and synaptic vesicles. ${ }^{50,56)}$ In an animal study, ferroportin-mRNA and ferroportin-protein expression were observed to be inhibited after the injection of hepcidin in rats, and ferroportin expression was observed to be decreased in cerebral cortex and hypocampus neurons. The authors suggested that hepcidin may bind to ferroportin in the brain to induce internalization and degradation of ferroportin. This action may block the cellular iron flux from the neuron. ${ }^{36)}$ In a study by Wang et al.., ${ }^{57)}$ 
ferroportin expression was shown to be inhibited in the murine brain that received hepcidin. According to these findings in the literature, the high level of hepcidin observed in ADHD patients in our study was thought to affect the administration, use, and release of iron in the cell by acting through ferroportin.

Furthermore, DMT1 is a transmembrane protein. ${ }^{58)}$ It is a key protein for transmembrane iron transport as well as iron translocation from endosomes. The regions, where DMT1 excretion is high in brain, are the basal ganglion nuclei such as caudate nucleus, putamen, and the pars reticulata of the substantia nigra. ${ }^{59)}$ In a study by Li et al., ${ }^{36)}$ DMT1 protein upregulation was observed in rat brains injected with hepcidin. High hepcidin levels in the ADHD group may negatively affect the iron transportation and use by affecting DMT1 levels, which has a main role in cellular iron homeostasis.

The exact mechanism whereby iron is transferred to the brain remains unclear. However, the generally accepted opinion is that iron enters the brain by binding to TfR1, which are excreted on the luminal surfaces of brain capillary endothelial cells. Iron separates from transferrin following the receptor-mediated endocytosis, and then it is transported either through the endosomal membrane, or released from the brain capillary endothelial cells towards the brain parenchyma. ${ }^{55)}$ In a previous report, the effects of hepcidin on the uptake and release of transferrinbound iron (Tf-Fe) and non-transferrin bound iron (NTBI) were investigated. As a result of the study, hepcidin was observed to inhibit Tf-Fe and NTBI uptake and iron release in astrocytes. Additionally, hepcidin significantly suppressed the expressions of TfR1 and DMT1 (which are iron uptake proteins) and FPN1 (which is an iron release protein). TfR1 expression was also found to be decreased by hepcidin directly and through cAMP-protein kinase A with iron-independent effect. Based on their findings, the authors proposed that there might be a receptor for hepcidin on the surface of the astrocyte. Furthermore, hepcidin may be effective in its action on this receptor. They pointed out that hepcidin could have effects in the regulation of the iron balance in the brain cells as well as the amount of iron influx and efflux to the brain. ${ }^{37)}$ In conclusion, high hepcidin levels in ADHD patients may also affect iron regulation through alteration on TfR1 expression.

Taken together with the previous literature, the role of hepcidin on impaired iron regulation in ADHD is very intriguing. ${ }^{31)}$ In our study, hepcidin levels in ADHD patients were found to be significantly higher than the healthy control group. Certainly, our work should be reviewed with its limitations. One of the greatest limitations of our study is the measured serum hepcidin levels. Studies evaluating the levels of hepcidin in the brain would yield better results. It may be helpful that to measure both peripheral and cerebral hepcidin levels simultaneously in future studies. Increasing the sample size may also contribute to more objective results. Recently, the literature suggests that neurodevelopmental diseases such as ADHD might be related to gut microbiota. ${ }^{60)}$ In our study, there was no microbiological evaluation made in ADHD cases. Future work would benefit from determining the association of the gut microbiota with ADHD. Considering the antibacterial properties of hepcidin, assessment of intestinal microbiotics with hepcidin in ADHD cases may provide a different perspective to the disease. Interestingly, several studies suggest that restless legs syndrome (RLS)/periodic limb movements (PLM) might be associated with both ADHD and hepcidin. ${ }^{61,62)}$ The ADHD cases in our study did not report any problems related to RLS/PLM. However, detailed evaluation regarding to RLS/PLM has not been done and this may be regarded as a limitation to our work. Groups were strictly selected and exclusion critiera was done to remove any patients that had complications that would affect the level of hepcidin (infections, hypoxia, etc.). We believe that this was strength of our work.

In conclusion, serum hepcidin levels were found to be significantly higher in patients with ADHD compared to healthy controls. However, there is still a need for more studies to determine whether hepcidin, which is considered as the main protein in the regulation of iron in the body, plays a role in ADHD.

\section{REFERENCES}

1. Willcutt EG. The prevalence of DSM-IV attention-deficit/hyperactivity disorder: a meta-analytic review. Neurotherapeutics 2012;9:490-499.

2. Taylor E. Antecedents of ADHD: a historical account of diagnostic concepts. Atten Defic Hyperact Disord 201 1;3:69-75.

3. Thapar A, Cooper M, Jefferies R, Stergiakouli E. What causes attention deficit hyperactivity disorder? Arch Dis Child 2012; 97:260-265.

4. Swanson JM, Kinsbourne M, Nigg J, Lanphear B, Stefanatos GA, Volkow N, et al. Etiologic subtypes of attention-defi- 
cit/hyperactivity disorder: brain imaging, molecular genetic and environmental factors and the dopamine hypothesis. Neuropsychol Rev 2007;17:39-59.

5. Andrews NC. Disorders of iron metabolism. N Engl J Med 1999;341:1986-1995.

6. Cortese $\mathrm{S}$, Lecendreux $\mathrm{M}$, Bernardina BD, Mouren MC, Sbarbati A, Konofal E. Attention-deficit/hyperactivity disorder, Tourette's syndrome, and restless legs syndrome: the iron hypothesis. Med Hypotheses 2008;70:1128-1132.

7. Wigglesworth JM, Baum $\mathrm{H}$. Iron dependent enzymes in the brain. In: Youdim $\mathrm{MBH}$, editor. Brain iron: Neurochemical and behavioral aspects. New York:Taylor and Francis; 1988. p.25-66.

8. Erikson KM, Jones BC, Beard JL. Iron deficiency alters dopamine transporter functioning in rat striatum. J Nutr 2000;130: 2831-2837.

9. Erikson KM, Jones BC, Hess EJ, Zhang Q, Beard JL. Iron deficiency decreases dopamine $D 1$ and $D 2$ receptors in rat brain. Pharmacol Biochem Behav 2001;69:409-418.

10. Youdim MB, Ben-Shachar D, Yehuda S. Putative biological mechanisms of the effect of iron deficiency on brain biochemistry and behavior. Am J Clin Nutr 1989;50(3 Suppl): 607-615; discussion 615-617.

11. Castellanos FX. Toward a pathophysiology of attention-deficit/hyperactivity disorder. Clin Pediatr (Phila) 1997;36:381-393.

12. Lozoff B, Beard J, Connor J, Barbara F, Georgieff M, Schallert T. Long-lasting neural and behavioral effects of iron deficiency in infancy. Nutr Rev 2006;64:S34-S43; discussion S72S91.

13. Cortese S, Angriman M, Lecendreux M, Konofal E. Iron and attention deficit/hyperactivity disorder: What is the empirical evidence so far? A systematic review of the literature. Expert Rev Neurother 2012;12:1227-1240.

14. Wang Y, Huang L, Zhang L, Qu Y, Mu D. Iron Status in attention-deficit/hyperactivity disorder: a systematic review and meta-analysis. PLoS One 2017;12:e0169145.

15. Konofal E, Lecendreux M, Arnulf I, Mouren MC. Iron deficiency in children with attention-deficit/hyperactivity disorder. Arch Pediatr Adolesc Med 2004;158:1113-1115.

16. Konofal E, Cortese S, Marchand M, Mouren MC, Arnulf I, Lecendreux M. Impact of restless legs syndrome and iron deficiency on attention-deficit/hyperactivity disorder in children. Sleep Med 2007;8:711-715.

17. Juneja M, Jain R, Singh V, Mallika V. Iron deficiency in Indian children with attention deficit hyperactivity disorder. Indian Pediatr 2010;47:955-958.

18. Calarge C, Farmer C, DiSilvestro R, Arnold LE. Serum ferritin and amphetamine response in youth with attention-deficit/hyperactivity disorder. I Child Adolesc Psychopharmacol 2010;20:495-502.

19. Lahat E, Heyman E, Livne A, Goldman M, Berkovitch M, Zachor D. Iron deficiency in children with attention deficit hyperactivity disorder. Isr Med Assoc J 2011;13:530-533.
20. Mahmoud MM, El-Mazary AA, Maher RM, Saber MM. Zinc, ferritin, magnesium and copper in a group of Egyptian children with attention deficit hyperactivity disorder. Ital / Pediatr 2011;37:60.

21. Cortese S, Azoulay R, Castellanos FX, Chalard F, Lecendreux $\mathrm{M}$, Chechin $\mathrm{D}$, et al. Brain iron levels in attention-deficit/hyperactivity disorder: a pilot MRI study. World I Biol Psychiatry 2012;13:223-231.

22. Bener A, Kamal M, Bener H, Bhugra D. Higher prevalence of iron deficiency as strong predictor of attention deficit hyperactivity disorder in children. Ann Med Health Sci Res 2014; 4(Supp/ 3):S291-S297.

23. Bala KA, Doğan M, Kaba S, Mutluer T, Aslan O, Doğan SZ. Hormone disorder and vitamin deficiency in attention deficit hyperactivity disorder $(A D H D)$ and autism spectrum disorders (ASDs). J Pediatr Endocrinol Metab 2016;29:1077-1082.

24. Millichap JG, Yee MM, Davidson SI. Serum ferritin in children with attention-deficit hyperactivity disorder. Pediatr Neurol 2006;34:200-203.

25. Menegassi M, Mello ED, Guimarães LR, Matte BC, Driemeier $\mathrm{F}$, Pedroso GL, et al. Food intake and serum levels of iron in children and adolescents with attention-deficit/hyperactivity disorder. Rev Bras Psiquiatr 2010;32:132-138.

26. Kiddie JY, Weiss MD, Kitts DD, Levy-Milne R, Wasdell MB. Nutritional status of children with attention deficit hyperactivity disorder: a pilot study. Int I Pediatr 2010;2010: 767318.

27. Kwon HJ, Lim MH, Ha M, Kim EJ, Yoo SJ, Kim JW, et al. Transferrin in Korean children with attention deficit hyperactivity disorder. Psychiatry Investig 2011;8:366-371.

28. Donfrancesco R, Parisi P, Vanacore N, Martines F, Sargentini $\mathrm{V}$, Cortese S. Iron and ADHD: time to move beyond serum ferritin levels. J Atten Disord 2013;17:347-357.

29. Percinel I, Yazici KU, Ustundag B. Iron deficiency parameters in children and adolescents with attention-deficit/hyperactivity disorder. Child Psychiatry Hum Dev 2016;47:259269.

30. Adisetiyo V, Jensen JH, Tabesh A, Deardorff RL, Fieremans E, Di Martino A, et al. Multimodal MR imaging of brain iron in attention deficit hyperactivity disorder: a noninvasive biomarker that responds to psychostimulant treatment? Radiology 2014;272:524-532.

31. Adisetiyo V, Helpern JA. Brain iron: a promising noninvasive biomarker of attention-deficit/hyperactivity disorder that warrants further investigation. Biomark Med 2015;9:403-406.

32. Park $\mathrm{CH}$, Valore EV, Waring AJ, Ganz T. Hepcidin, a urinary antimicrobial peptide synthesized in the liver. I Biol Chem 2001;276:7806-7810.

33. Fleming RE, Bacon BR. Orchestration of iron homeostasis. $N$ Eng/J Med 2005; 352:1741-1744.

34. Pigeon C, Ilyin G, Courselaud B, Leroyer P, Turlin B, Brissot $\mathrm{P}$, et al. A new mouse liver-specific gene, encoding a protein homologous to human antimicrobial peptide hepcidin, is over- 
expressed during iron overload. J Biol Chem 2001;276:78117819.

35. Zechel S, Huber-Wittmer K, von Bohlen und Halbach O. Distribution of the iron-regulating protein hepcidin in the murine central nervous system. J Neurosci Res 2006;84:790800.

36. Li L, Holscher C, Chen BB, Zhang ZF, Liu YZ. Hepcidin treatment modulates the expression of divalent metal transporter-1, ceruloplasmin, and ferroportin-1 in the rat cerebral cortex and hippocampus. Biol Trace Elem Res 2011;143: 1581-1593.

37. Du F, Qian C, Qian ZM, Wu XM, Xie H, Yung WH, et al. Hepcidin directly inhibits transferrin receptor 1 expression in astrocytes via a cyclic AMP-protein kinase A pathway. Glia 2011;59:936-945.

38. Kaufman J, Birmaher B, Brent D, Rao U, Flynn C, Moreci P, et al. Schedule for Affective Disorders and Schizophrenia for School-Age Children-Present and Lifetime version (K-SADS-PL): initial reliability and validity data. I Am Acad Child AdolesC Psychiatry 1997;36:980-988.

39. Gökler B, Ünal F, Pehlivantürk B, Kültür EÇ, Akdemir D, Taner $\mathrm{Y}$. Reliability and validity of schedule for affective disorders and schizophrenia for school age children-present and lifetime version-Turkish version (K-SADS-PL-T). Turk I Child Adolesc Ment Health 2004;11:109-116.

40. Turgay A. Disruptive behavior disorders: Child and Adolescent Screening and Rating Scales for Children, Adolescents, Parents and Teachers. West Bloomfield, MI:Integrative Therapy Institute Publication; 1994.

41. Ercan ES, Amado S, Somer O, Çıkoğlu S. Development of a test battery for the assessment of attention deficit hyperactivity disorder. J Child Adolesc Ment Health 2001;8:132-144.

42. Conners CK, Sitarenios G, Parker JD, Epstein JN. The revised Conners' Parent Rating Scale (CPRS-R): factor structure, reliability, and criterion validity. I Abnorm Child Psychol 1998;26:257-268.

43. Kaner S, Büyüköztürk Ş, İşeri E, Ak A, Özaydın L. Conners' parent rating scale long form-revised: factor structure, reliability and validity studies. Turk I Child Adolesc Mental Health 2011;18:45-58.

44. Conners CK, Sitarenios G, Parker JD, Epstein JN. Revision and restandardization of the Conners Teacher Rating Scale (CTRS-R): factor structure, reliability, and criterion validity. J Abnorm Child Psychol 1998;26:279-291.

45. Kaner S, Buyukozturk S, Iseri E, Ak A, Ozaydin L. The validity and reliability study of the Turkish version of Conners' Teacher Rating Scale-Revised (CTRS-R). In: Proceedings of World Psychiatric Association International Congress; Jul 12-16, 2006; Istanbul, Turkey.

46. Savaşır I, Şahin N. /Wechsler Intelligence Scale for Children (WISC-R)]. Ankara:Turkish Psychological Association;1995. Turkish.

47. Du F, Qian ZM, Luo Q, Yung WH, Ke Y. Hepcidin suppresses brain iron accumulation by downregulating iron transport proteins in iron-overloaded rats. Mol Neurobiol 2015;52: 101-114.

48. Simpson IA, Ponnuru P, Klinger ME, Myers RL, Devraj K, Coe $\mathrm{CL}$, et al. A novel model for brain iron uptake: introducing the concept of regulation. J Cereb Blood Flow Metab 2015;35: 48-57.

49. Qian ZM, To Y, Tang PL, Feng YM. Transferrin receptors on the plasma membrane of cultured rat astrocytes. Exp Brain Res 1999; 129:473-476.

50. Burdo JR, Menzies SL, Simpson IA, Garrick LM, Garrick MD, Dolan KG, et al. Distribution of divalent metal transporter 1 and metal transport protein 1 in the normal and Belgrade rat. I Neurosci Res 2001;66:1198-1207.

51. Jiang DH, Ke Y, Cheng YZ, Ho KP, Qian ZM. Distribution of ferroportin1 protein in different regions of developing rat brain. Dev Neurosci 2002;24:94-98.

52. Nemeth E, Ganz T. Regulation of iron metabolism by hepcidin. Annu Rev Nutr 2006;26:323-342.

53. Donovan A, Brownlie A, Zhou Y, Shepard J, Pratt SJ, Moynihan J, et al. Positional cloning of zebrafish ferroportin1 identifies a conserved vertebrate iron exporter. Nature 2000; 403:776-781.

54. Anderson GJ, Vulpe CD. Mammalian iron transport. Cell Mol Life Sci 2009;66:3241-3261.

55. Moos T, Rosengren Nielsen T, Skjørringe T, Morgan EH. Iron trafficking inside the brain. I Neurochem 2007;103:17301740.

56. Wu LJ, Leenders AG, Cooperman S, Meyron-Holtz E, Smith S, Land W, et al. Expression of the iron transporter ferroportin in synaptic vesicles and the blood-brain barrier. Brain Res 2004;1001:108-117.

57. Wang SM, Fu LJ, Duan XL, Crooks DR, Yu P, Qian ZM, et al. Role of hepcidin in murine brain iron metabolism. Cell Mol Life Sci 2010;67:123-133.

58. Song N, Jiang H, Wang J, Xie JX. Divalent metal transporter 1 up-regulation is involved in the 6-hydroxydopamine-induced ferrous iron influx. J Neurosci Res 2007;85:3118-3126.

59. Knutson M, Menzies S, Connor J, Wessling-Resnick M. Developmental, regional, and cellular expression of SFT/UbcH5A and DMT1 mRNA in brain. I Neurosci Res 2004;76:633-641.

60. Cenit MC, Nuevo IC, Codoñer-Franch P, Dinan TG, Sanz Y. Gut microbiota and attention deficit hyperactivity disorder: new perspectives for a challenging condition. Eur Child Adolesc Psychiatry 2017;26:1081-1092.

61. Cortese S, Brown TE, Corkum P, Gruber R, O'Brien LM, Stein $\mathrm{M}$, et al. Assessment and management of sleep problems in youths with attention-deficit/hyperactivity disorder. I Am Acad Child Adolesc Psychiatry 2013;52:784-796.

62. Clardy SL, Wang X, Boyer PJ, Earley CJ, Allen RP, Connor JR. Is ferroportin-hepcidin signaling altered in restless legs syndrome? J Neurol Sci 2006;247:173-179. 